\title{
Population structure and reproductive biology of Haemulopsis corvinaeformis (Perciformes, Haemulidae) in the south coast of Pernambuco, northeastern Brazil
}

\author{
Leandro N. Eduardo (1) https://orcid.org/0000-0003-2369-4175 \\ Alex S. Lira (iD) https://orcid.org/0000-0003-1734-1875 \\ Thierry Frédou (10) https://orcid.org/0000-0002-0510-6424 \\ Flavia Lucena Frédou (10) https://orcid.org/0000-0001-5492-7205
}

Universidade Federal Rural de Pernambuco, Departamento de Pesca e Aquicultura, Laboratório de Estudos de Impactos Antrópicos na Biodiversidade Marinha e Estuarina (BIOIMPACT), 52171-900, Recife, PE, Brazil. (leandronole@hotmail.com; alex.lira@ufrpe.br; thierry.fredou@ufrpe.br; flavia.lucena@pq.cnpq.br)

Received 5 June 2017

Accepted 12 March 2018

Published 11 June 2018

DOI $10.1590 / 1678-4766 e 2018007$

\begin{abstract}
Roughneck Grunt (Haemulopsis corvinaeformis Steindachner, 1868) is the second most important species caught as bycatch of the shrimp fishery in Pernambuco, Northeastern Brazil. However, the population dynamic of this species is poorly known in the region. The aim of this study was to describe aspects of the population structure and reproductive biology of the $H$. corvinaeformis, providing important information for the development of sustainable management practices. Specimens were collected monthly from August 2011 to July 2012 and quarterly from October 2012 to June 2014 . A total of 1,140 individuals was collected; 340 males (29.8\%), 391 females (34.3\%), and 409 were immature and could not be sexed (35.9\%). Total length ranged from 7 to $25 \mathrm{~cm}$. In general, total length of females [12.85 $\pm 2.49 \mathrm{~cm}($ mean $\pm \mathrm{SD})]$ and males $[12.72 \pm 2.46 \mathrm{~cm}(\mathrm{mean} \pm \mathrm{SD})]$ were $\operatorname{similar}(\mathrm{p}>0.05)$. The proportion of males and females was similar along the year, except in March. The relationship between total length and total weight was statistically significant $(\mathrm{p}<0.05)$, showing an isometric growth. The (GSI) coupled with the distribution of maturational stages suggests that females reproduce all year around, with a peak during October-November. The length at first maturity $\left(\mathrm{L}_{50}\right)$ was estimated at $11.88 \mathrm{~cm}$ for females and $11 \mathrm{~cm}$ for males.
\end{abstract}

KEYWORDS. Dynamic population, gonadosomatic index, isometric growth.

RESUMO. Aspectos da estrutura populacional e biologia reprodutiva do Haemulopsis corvinaeformis em Pernambuco, nordeste do Brasil. O coró branco (Haemulopsis corvinaeformis Steindachner, 1868) é a segunda espécie mais importante capturada como fauna acompanhante na pesca de camarão em Pernambuco, nordeste do Brasil. No entanto, a dinâmica populacional é pouco conhecida na região. O objetivo do estudo foi descrever aspectos da estrutura populacional e biologia reprodutiva da espécie, fornecendo informações importantes para o desenvolvimento de práticas de manejo sustentáveis. Espécimes foram coletados mensalmente de agosto de 2011 a julho de 2012, e a cada três meses de outubro de 2012 a junho de 2014. Um total de 1.140 espécimes foi coletado; 340 machos $(29,8 \%), 391$ fêmeas $(34,3 \%)$, e 409 imaturos cujo sexo não pode ser identificado (35,9\%). O comprimento total variou entre 7 e $25 \mathrm{~cm}$. De maneira geral, o comprimento total das fêmeas $[12,85 \pm 2,49 \mathrm{~cm}(\mathrm{média} \pm \mathrm{DP})]$ e machos $[12,72 \pm 2,46$ $\mathrm{cm}($ média $\pm \mathrm{DP})]$ foram similares $(\mathrm{p}>0.05)$. A proporção de machos e fêmeas foi similar, com exceção de março. As relações entre comprimento total e peso total foram estatisticamente significantes $(\mathrm{p}<0.05)$, mostrando um crescimento isométrico. O índice gonadossomático (GSI) associado com a distribuição dos estágios maturacionais sugerem que as fêmeas reproduzem durante todo o ano, com um pico durante outubro-novembro. O tamanho de primeira maturação foi estimado em $11.88 \mathrm{~cm}$ para fêmeas e $11 \mathrm{~cm}$ para machos.

PALAVRAS-CHAVE. Dinâmica populacional, índice gonadossomático, crescimento isométrico.

Bycatch is the retained catch of non-targeted but commercially valuable species or species consumed by crew, used for bait, or rejected at port or at sea (GILMAN et al., 2013). These non-targeted species are a common feature of nearly all commercial fisheries, both industrial and artisanal. In many fisheries, all or most of the bycatch may be discarded (KELLEHER, 2005). This incidental catch contributes to alterations in the ecosystem, decline of populations and catch of juveniles and endangered species (PASCOE, 1997; BroAdHURST et al., 2006; Cox et al., 2007). Several United Nations resolutions have drawn attention to the need for monitoring and better understanding bycatch, in order to assess the impact of discards on marine resources to produce solutions to reduce its effects (KELLEHER, 2005).

The Roughneck Grunt Haemulopsis corvinaeformis (Steindachner, 1868) (Perciformes: Haemulidae) is the second most important species caught as bycatch of the shrimp fishery in Pernambuco, Northeastern Brazil, representing $10 \%$ of the total biomass. This species occurs in the Western Atlantic, from Mexico to Southern Brazil (SмiтH, 1997). It is a small-sized species, reaching a maximum of $25 \mathrm{~cm}$, inhabits sandy and rocky bottoms of coastal waters and is 
found to a depth of $50 \mathrm{~m}$ (Courtenay \& Sahlman, 1978; CERVIGón et al., 1992). The species has an important role in the food chain, either feeding on components of the system (e.g. small fishes, shrimps and copepods) (Denadai et al., 2013) or integrating the diet of other fishes. Furthermore, this species serves as a food source for local fishers (CHAVES \& CORRÊA, 2000; GARCIA et al., 2010).

Despite the abundance and ecological importance of this species, relatively few studies on its population dynamics have been carried out. Investigations regarding this species in Brazil are restricted to the coast of the states of Ceará (COSTA \& SAntos,1995), Rio Grande do Norte (Silva et al., 2012), Paraná (Costa \& Santos, 1995; Chaves, 1998) and Santa Catarina (Souza \& Chaves, 2007). Consequently, required information for the conservation of $H$. corvinaeformis is still absent in many places along the Brazilian coast. Among the essential information required for the stock management and conservation, we may mention the population structure and aspects of the reproductive biology, as the mean length of maturation and breeding season, necessary to establish minimum catch sizes, closed season or no take areas (KING, 2007). However, when absent, the lack of information hampers the ability of managers to make a sustainable decision, and considering our study case, may threat the local food security.

In this context, the aim of this study was to describe the mean length of maturation, breeding season and population structure of the species $H$. corvinaeformis caught as shrimptrawl bycatch in the south of Pernambuco, providing essential information for the development of sustainable management practices.

\section{MATERIAL AND METHODS}

The study site is in the Southern coast of Pernambuco, northeast of Brazil, in the coastal area of the city of Sirinhaém. This region has the largest and most productive motorized fishing fleet among the coastal cities of Pernambuco (TisCHER \& SANTOS, 2002). Samples were collected in the coastal zone, near


Fig. 1. Study area in the coast of state of Pernambuco, northeastern Brazil. Black dots represent fishing sites. 
the Santo Aleixo Island ( $08^{\circ} 35^{\prime} 57^{\prime}$ '-08 $36^{\circ} 57^{\prime}$ 'S, 34 $56^{\circ} 58^{\prime \prime}$ $35^{\circ} 00^{\prime} 48^{\prime \prime}$ W; Fig. 1) at a depth of 10 to $20 \mathrm{~m}$ (Fig.1).

Specimens of $H$. corvinaeformis were collected from the bycatch of an artisanal shrimp outrigger trawler from the local fleet, from August 2011 to July 2012 and every three months from October 2012 to June 2014. The fishery was carried out by day at full moon using two bottom otter trawls that sampled across sectional area of water on the bottom approximately $10 \mathrm{~m}$ wide and $6.1 \mathrm{~m}$ deep. Mesh size of $30 \mathrm{~mm}$ guided the fish to a $25-\mathrm{mm}$ mesh in the cod end. Every sample consisted of three trawling tows that were two hours long. Once collected, the specimens were immediately put on ice onboard, then transported to the laboratory and stored in a freezer $\left(-18^{\circ} \mathrm{C}\right)$ until the analysis. The surface water temperature was measured for each sample using a multiparameter. Pluviometric data were obtained through the Agência Pernambucana de Águas e Clima (APAC). For a better characterization of the seasons, we used the historical average accumulation of rainfall per month of the years 2002 to 2012 .

For all individuals, total length (TL), standard length (SL) and the total weight (TW) were recorded. Subsequently, a ventral-longitudinal incision was made and the gonads removed for macroscopic sex and maturation stage determination. Eviscerated fish and gonads were weighed to the nearest $0.01 \mathrm{~g}$. The maturation stages were classified according to the scale proposed by VAZZOLER (1996): stages A, immature; B, maturing; C, mature, and D, spawned or resting.

The population structure was described by considering months and sexes. To determine significant differences in TL between them, a two-way ANOVA [data $\log 10(\mathrm{x}+1)$ transformed] was performed (SOKAL \& ROHLF, 1987) following the necessary assumptions of normality (Kolmogorov-Smirnov test) and homoscedasticity (Levene's test). The Tukey's post-hoc test was used to determine significant differences between months and sexes (ZAR, 2009). The sex-ratios, determined totally, by month and size classes $(1 \mathrm{~cm})$, were statistically tested for significant deviations from the expected 1:1 ratio with a $\chi^{2}$ test $(\alpha=$ 0.05) (DAGNelie, 1975).

A regression analysis was applied to estimate biometric relationships, where the total length (TL) was the independent variable and total weight (TW) was the dependent variable. These relationships were determined separately for both sexes and pooled sexes. The relation is isometric when $b=3$, hypoallometric or negative allometric when $b<3$, and hyperallometric or positive allometric when $\mathrm{b}>3$. The null hypothesis of the isometric growth (H0: $b$ $=3$ ) was tested by $\mathrm{t}$ - test, using the statistic: $\mathrm{t}_{\mathrm{s}}=(\mathrm{b}-3) / \mathrm{S}_{\mathrm{b}}$, where $\mathrm{Sb}$ is the standard error of the slope, for $\alpha=0.05$ for testing significant differences among slopes (b) between two regressions for the same species (ZAR, 2009). The differences between males and females were also compared by the Student's t-test. The fit of the model to the data was measured by the coefficient of Pearson r-squared $\left(\mathrm{R}^{2}\right)$.
To analyze tmaturhe size at first maturity $\left(\mathrm{L}_{50}\right)$ (length at which $50 \%$ of the individuals attain gonadal maturity for the first time), the percentage of adults (stages B, C and D) by length was calculated and considered as dependent variable $(\mathrm{Y})$, and the total length as the independent variable (X). Next, these values were adjusted by the least-squares method to a logistic curve, which is given according to KING (2007): $\left.\mathrm{P} i=1 /\left(1+\mathrm{e}^{-\mathrm{r}(\mathrm{L} i-\mathrm{L}}{ }_{50}\right)\right)$, where $\mathrm{P} i=$ the proportion of adult individuals for each class $i, \mathrm{~L} i=$ total length at each class $i$, $\mathrm{L}_{50}=$ total length that corresponds to $0.5(50 \%)$ proportion of adults and $\mathrm{r}=$ the logistic curve slope. $\mathrm{L}_{50}$ was obtained for males, females and polled sexes. Also, a confidence interval of $95 \%$ was calculated for each value of $\mathrm{L}_{50}$.

The spawning season was evaluated considering data collected from August 2011 to June 2012, through the relative frequency of the gonadal maturation stages and by calculating the Gonadosomatic Index (GSI) bimonthly for females, based on VAzzoLER (1996): GSI $=(\mathrm{GW} / \mathrm{TW}) * 100$, Where $\mathrm{GW}=$ gonad weight and TW = total weight of the specimen. This analysis included only adult females (those at the same size or larger than the length at first sexual maturity calculated in this study). Kruskal-Wallis test (given that the assumptions of parametric tests were not met) was used ( $p$ $<0.05$ ) to compare differences of the GSI between months.

The Spearman's rank correlation was used to measure the strength of the relation between temperature and rainfall, with GSI values and percentage of mature females (stage $\mathrm{C}$ ).

\section{RESULTS}

A total of 1,140 specimens of $H$. corvinaeformis was collected; 340 males (29.8\%), 391 females (34.3\%), and 409 immatures (35.9\%), which could not be sexed. Total length ranged from 7 to $25 \mathrm{~cm}$ (males 7.1-19.8 cm, females 7- 25 $\mathrm{cm}, \mathrm{TL}$ ), and the total weight oscillated from 4.2 to $117 \mathrm{~g}$ (males 4.5-104.6g, females 4.2-117 g, TW). The highest number of individuals for pooled sexes of TL occurred in the length class of $12-13 \mathrm{~cm}$. In general, total length of females $[12.85 \pm 2.49 \mathrm{~cm}($ mean $\pm \mathrm{SD})]$ and males $[12.72 \pm 2.46 \mathrm{~cm}$ $($ mean \pm SD)] were similar $(\mathrm{p}>0.05)$ (Fig. 2). Except for the month of July, individuals of $H$. corvinaeformis were found throughout the year.

The largest individuals were caught in April, with a mean TL of $15 \mathrm{~cm}(\mathrm{SD} \pm 2 \mathrm{~cm})$. The smallest individuals were observed in May and June, with a mean total length of $11.9 \mathrm{~cm}(\mathrm{SD} \pm 1.2 \mathrm{~cm})$ and $11.9 \mathrm{~cm}(\mathrm{SD} \pm 2.1 \mathrm{~cm})$, respectively (Fig. 3). Considering the whole period, TL of males and females did not differ significantly $(p<0.05)$ (Fig. $3)$. However, females were larger than males in October, November, January, April and June (p < 0.05) (Fig. 3). Overall, there was no predominance of males over females $(1.02: 1)\left(\chi^{2}, p>0.05\right)$. The same pattern was observed in all length classes and months, except in March, where males were more abundant than females (Fig. 3) $\left(\chi^{2}, p<0.05\right)$.

The regression analysis between TL and TW for females, males and pooled sexes were significant $(p<0.05)$, showing an 


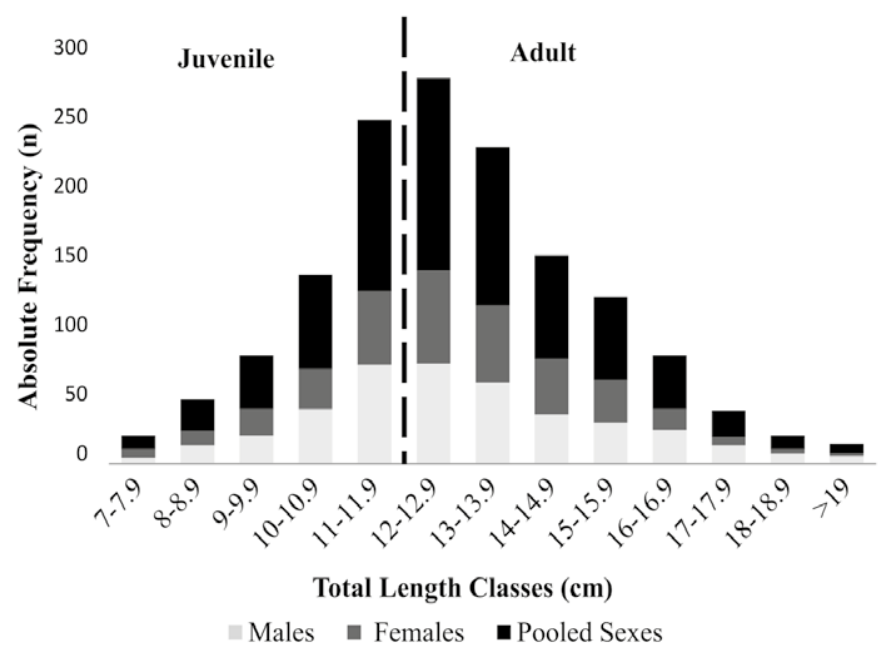

Fig. 2. Absolute frequency distribution per length classes of males, females and pooled sexes for Roughneck Grunt, Haemulopsis corvinaeformis (Steindachner, 1868) captured from August 2011 to July 2014, off the coast of State of Pernambuco, northeastern Brazil. The vertical line represents the L50.

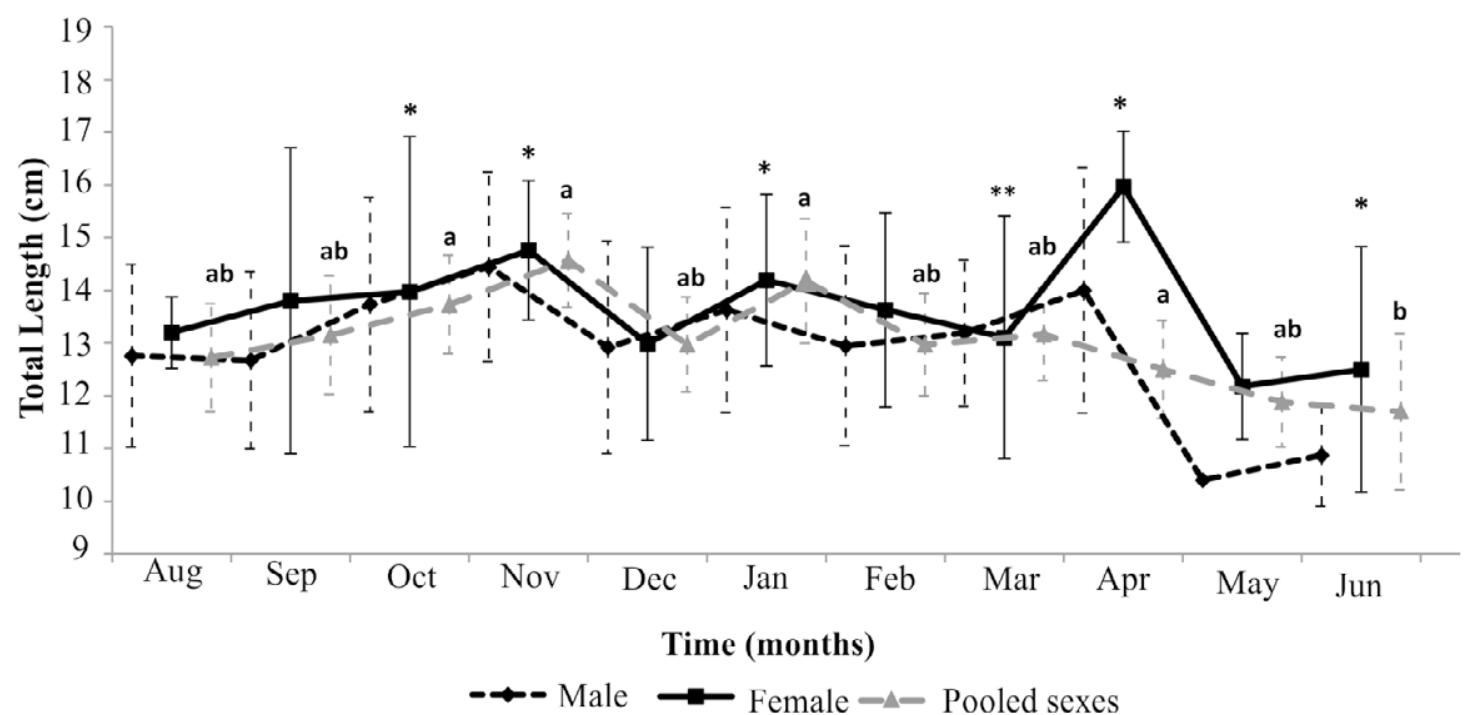

Fig. 3. Monthly average $( \pm \mathrm{SD})$ of the total length $(\mathrm{TL}, \mathrm{cm})$ of males, females and pooled sexes of Roughneck Grunt, Haemulopsis corvinaeformis (Steindachner, 1868), captured from August 2011 to July 2012, off the coast of state of Pernambuco, northeastern Brazil. Different letters indicate significant size differences between months for pooled sexes $(*$, significant sizes differences between males and females; $* *$, significant differences in sexual ratio).

Tab. I. Descriptive statistics and TW-TL relationship parameters for the Roughneck Grunt, Haemulopsis corvinaeformis (Steindachner, 1868), captured from August 2011 to June 2014, off the coast of State of Pernambuco, northeastern Brazil [TL, total length (cm); SD, standard deviation; min, minimum; max, maximum; SL, standard length $(\mathrm{cm})$; TW, total weight]. Different superscript letters indicate significant differences between males and females. *, indicates significant allometric growth.

\begin{tabular}{|c|c|c|c|}
\hline & Males & Females & Pooled sexes \\
\hline TL, mean \pm S.D. & $12.72 \pm 2.46$ & $12.85 \pm 2.49$ & $12.72 \pm 2.24$ \\
\hline$\left(\mathrm{TL}_{\min }-\mathrm{TL}_{\max }\right)$ & $(7.1-19.8)$ & $(7-25)$ & $(6.3-25)$ \\
\hline $\mathrm{SL}$, mean \pm S.D. & $10.48 \pm 1.86$ & $10.56 \pm 2.02$ & $10.10 \pm 2.10$ \\
\hline$\left(\mathrm{SL}_{\min }-\mathrm{SL}_{\max }\right)$ & $(5.9-16)$ & $(5.6-17.5)$ & $(5.3-17.5)$ \\
\hline Weight characteristics (g) & & & \\
\hline $\mathrm{TW}$, mean \pm S.D. & $30.5 \pm 12.05$ & $31.2 \pm 18.41$ & $28 \pm 17.52$ \\
\hline$\left(\mathrm{TW}_{\min }-\mathrm{TW}_{\max }\right)$ & $(4.5-104.6)$ & $(4.2-117)$ & $(3-117)$ \\
\hline TL-TW equation & $\mathrm{TW}=0.019 \mathrm{TL}^{3.0469}$ & $\mathrm{TW}=0.0141 \mathrm{TL}^{2.9656}$ & $\mathrm{TW}=0.01251 \mathrm{TL}^{3.0265}$ \\
\hline Determination Coefficient $\left(\mathrm{r}^{2}\right)$ & 0.9396 & 0.9470 & 0.9592 \\
\hline t-test (Coefficient $b=3$ ) & $\mathrm{p}>0.05$ & $\mathrm{p}>0.05$ & $\mathrm{p}>0.05$ \\
\hline Growth Type & Isometric $^{\text {(a) }}$ & Isometric $^{(b)}$ & Isometric \\
\hline
\end{tabular}


isometric growth $(\mathrm{p}>0.05)$. The $b$ coefficients were different between males and females (TL $x$ SL and TL $x$ TW) (Tab. I).

Haemulopsis corvinaeformis is a gonochoristic species with no identifiable sexual dimorphism in body shape or color. Overall, $35.7 \%$ of the female specimens collected during the study were immature, $33.4 \%$ were maturing, $26.8 \%$ were mature, and $4.1 \%$ were spawned. Immature and mature individuals were always present, providing strong evidence that the species spawns all year around (Fig. 4). However, the mean gonadosomatic index was higher in October-November and then gradually decreased until JuneJuly. Also, the bimesters of October-November and AprilMay were statistically similar with each other $(p<0.05)$, with both presenting higher percentages of mature and spawned or resting individuals (April-May) (Fig. 4).

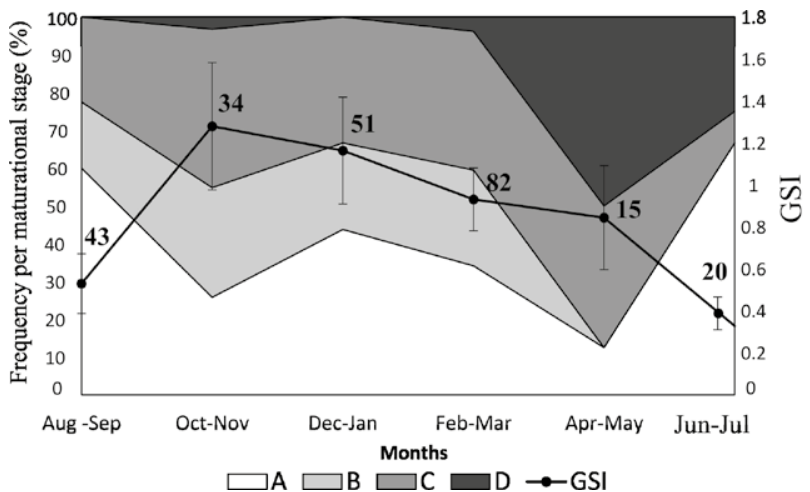

Fig. 4. Bimonthly changes in GSI ( \pm standard error) and frequency of the different gonadal stages for Roughneck Grunt, Haemulopsis corvinaeformis (Steindachner, 1868), captured from August 2011 to June 2012, off the coast of state of Pernambuco, northeastern Brazil (A, immature; B, maturing; C, mature; $\mathrm{D}$, spawned or resting). The numbers above the line represent the sample size of GSI analysis in each bimester.

The Spearman's rank correlation presented a nonsignificant relationship between temperature and rainfall with GSI values and percentage of mature females (stage C) $(\mathrm{p}>0.05)$.

The length at first maturity $\left(\mathrm{L}_{50}\right)$ was estimated as $11.88 \mathrm{~cm}(\mathrm{CI} \pm 0.45) \mathrm{TL}$ for females, $11 \mathrm{~cm}(\mathrm{CI} \pm 0.50) \mathrm{TL}$ for males and $11.45 \mathrm{~cm}(\mathrm{CI} \pm 0.35) \mathrm{TL}$ for pooled sexes. The smallest adult individual had a body length of $8.5 \mathrm{~cm}$, whereas all those with TL above $18.5 \mathrm{~cm}$ were adults (Fig. 5).

\section{DISCUSSION}

Fishing affects demersal fish communities through selective removal of target species, through the bycatch of non-target species, and through habitat modification. These alterations change populational parameters as overall biomass, species composition and size structure (BIANCHI et al., 2000). In this context, understanding variation of populational parameters of $H$. corvinaeformis through the space and time is fundamental to properly access anthropogenic impacts on this bycatch species. In the Southern coast of Pernambuco, the maximum lengths recorded $(25 \mathrm{~cm})$ for $H$. corvinaeformis
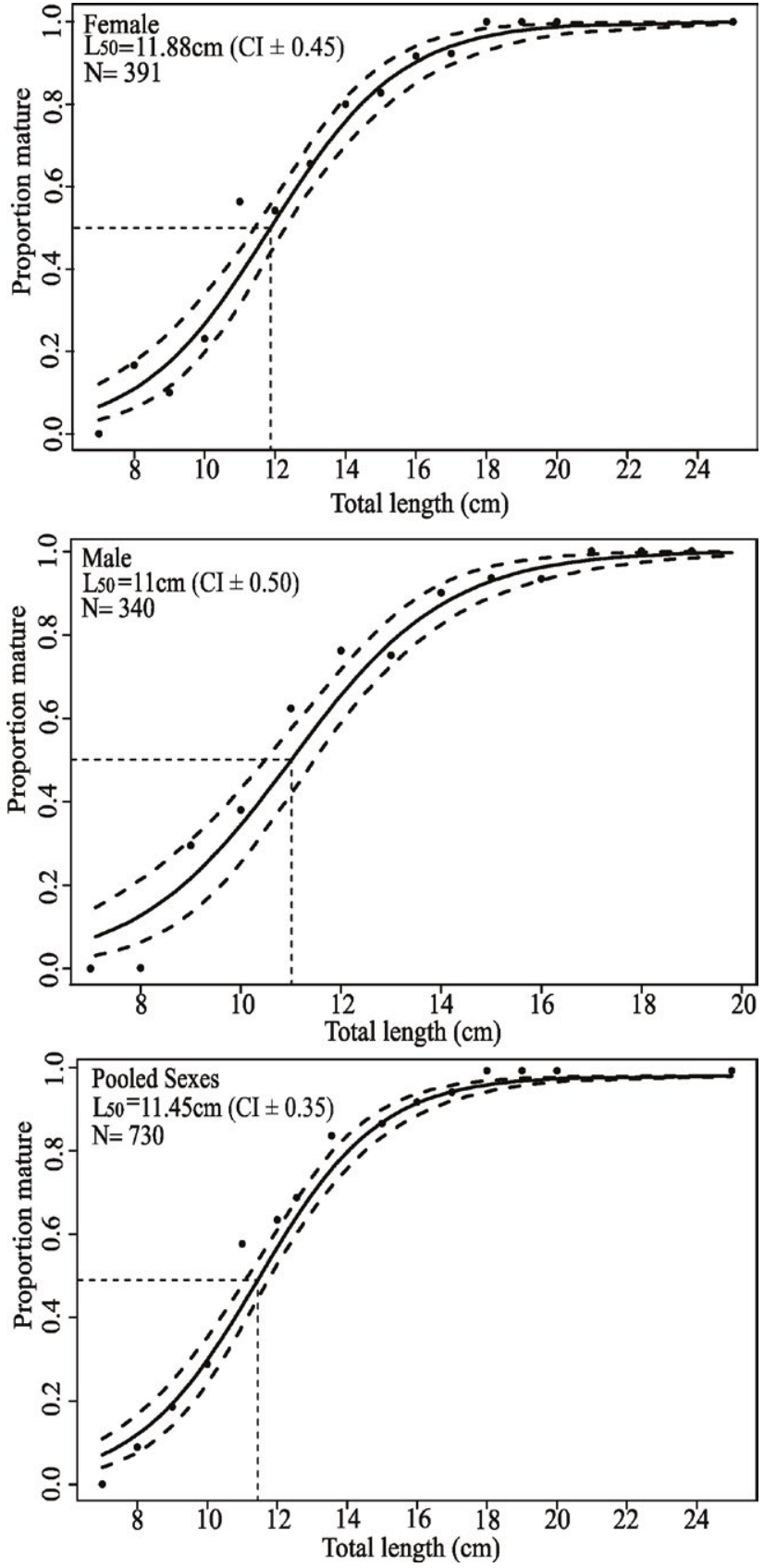

Fig. 5. Total length at first sexual maturity $\left(\mathrm{L}_{50}, \mathrm{~cm}\right)$ and confidence interval (IC, 95\%) for females, males and pooled sexes of Roughneck Grunt, Haemulopsis corvinaeformis (Steindachner, 1868), captured from August 2011 to June 2012, off the coast of state of Pernambuco, northeastern Brazil.

were greater than those recorded for the same species in other areas in Brazil: $12.5 \mathrm{~cm}$ in Caraguatatuba Bay, São Paulo (Denadai et al., 2013); $14.7 \mathrm{~cm}$ in Rio Grande do Norte (Silva et al., 2012); $18 \mathrm{~cm}$ in Ceará (Costa \& SANTOS, 1995); and $14 \mathrm{~cm}$ in Guaratuba Bay, Paraná (CHAVEs \& CorRÊA, 2000). Besides the influence of fishing, such size differences may be also related to the ecological characteristics of each region and/or fishing gear type, selectivity and/or area of exploitation (FRÉDOU et al., 2009).

The length-weight relationship (LWR) is very important for the fisheries management and for environmental 
monitoring programs (MoREy et al., 2003). It has been used to estimate the weight of individual fish from its length and compare fish populations or species from different regions and environment. The relationship allows to relate the changes of body shape and weight associated with different situations as growth, reproduction and anthropogenic impacts (LE CREN, 1951; Froese, 2006). Moreover, the $b$ value of the LWR relationship may also give indications of the beginning of reproductive events (LE CREN, 1951). In the present study, an isometric growth was observed, showing that the individuals did not change form along the ontogenetic growth. Isometric growth has also been observed for $H$. corvinaeformis in the Southern cost of Brazil (VIANNA et al., 2004). In addition, the growth pattern (male $b=3.0469$; female $b=2.9656$ ) found in this study was similar than those $(b=2.99)$ found by VianNa et al., (2004) and smaller than those find by Chaves (1998) ( $b=3.183)$ in Paraná, Brazil. Differences on pattern of growth may be explained by differences on food availability, population, sex, environmental conditions or physiology among studied areas (Froese, 2006).

Sex ratio provides important information of the relationship between individuals and environment and the population situation of each species. This tool also provides basic information for assessing population structure, reproductive potential and for estimating the size of population stock (STRATOUdAKIs et al., 2006). In the present study, the overall sex ratio was balanced between males and females $(1: 1)\left(\chi^{2}\right.$ test, $\left.p<0.05\right)$. The sex ratios were also balanced in all size classes and months, except in March, when males were more abundant than females. However, Silva et al. (2012) and Denadai et al. (2013) indicated a higher proportion of females of $H$. corvinaeformis in state of Rio Grande do Norte and a higher proportion of males in Caraguatatuba Bay, state of São Paulo, respectively. Although the reasons for these divergences are not clear, they might be related to differences in the ecosystems and increased fishing pressure in either one of the sexes, as they may have different growth rates, and thus, may be harvested differently (RIJNSDORP et al., 2010).

Gonadosomatic index (GSI) and proportion of maturation stages are important parameters to determine the spawning season of a species, which may be used to determine the ideal time and duration for a management action (Mian et al., 2017). In the present study, GSI coupled with the distribution of maturation stages suggest that females reproduce all year round, with a peak during October-November. The continuous reproduction observed to the species was also observed in Brazil in the states of Rio Grande do Norte (Silva et al., 2012), Santa Catarina (SouzA \& Chaves, 2007) and São Paulo (Denadai et al., 2013). In tropical regions, where seasonal temperature variations are low, the rainfall plays a decisive role in determining reproductive cycles (PARSONs et al., 2007; ChellapPa et al., 2010). MUNRo et al. (1973) reported that spawning of haemulids in Jamaica is related to water temperature, with a maximum spawning during the months with lowest temperatures, though some spawning occurs all months.
In our case, no relationship of temperature or rainfall to spawning was observed for this species. However, several other factors may be influencing the reproduction, such as differentiation in genetic combination, day light, turbidity, depth of water and availability of food (JASMINE \& MoLINA, 2016).

The constant occurrence of mature individuals throughout the year, mainly during October-November, suggests that $H$. corvinaeformis use the area during their reproductive period. In addition, the presence of immature individuals during all months indicates that the recruitment of the studied species also occurs throughout the year in the region. Thus, this information characterizes the study area as a place of considerable ecological importance for the species. Besides the ecological relevance for $H$. corvinaeformis, at least ten other species of Sciaenidae family use the area as reproduction site or transition zone for reproduction (SILVA et al., 2015a).

In reproduction studies, the definition of size at first gonadal maturity has a fundamental importance for the development of sustainable fishery management practices, given this parameter is widely used as the minimum threshold for the harvesting of stocks (FonTELES-FiLHO, 2011). In the present study, mean size at first maturity was $11.45 \mathrm{~cm}$ for pooled sexes, with similar values for females (11.88 $\mathrm{cm})$ and males $(11 \mathrm{~cm})$; which is slightly higher than the observed to Rio Grande do Norte $(10.3 \mathrm{~cm}$ for males and $10.4 \mathrm{~cm}$ for females) (Silva et al., 2012). Size at sexual maturity between populations of the same species can vary due to growth rates, fishing removals, fishing gears, food availability, and hydrologic conditions (CHAPMAN et al., 1996; Hood \& Johnson, 2000; PotTs \& MaNOOCH, 2001). Although the sampled specimens are certainly related to the selectivity of the fishing gear, considering the size at first maturity found in this study, less than $30 \%$ of individual are juveniles. It means that most of harvest individuals might have been able to reproduce and contribute for population renewal, representing a good indicator for the sustainability of the $H$. corvinaeformis stock.

Haemulopsis corvinaeformis is the second most important species caught as bycatch of the shrimp fishery in Pernambuco, with considerable ecological and social functions. However, most of bycatch organisms in Pernambuco, including H. corvinaeformis, have no fishing regulations or any control of the landings by the Brazilian authorities. Although successful strategies for managing these resources depend on interactions among highly heterogenous social, political and economic factors, the results of the present study, combined with other studies in the region, can be used to guide adequate management policies. A main step towards ensuring the long-term conservation of many species would be the use of bycatch reduction devices, which are tools designed to improve the selectivity of fishing gear and reduce bycatch in shrimp trawlers up to $40 \%$ (GARCIACAUdillo et al., 2000; BREwER et al., 2006). In addition, as shrimp trawlers off the coast of Pernambuco accidentally catch many species along with at least three shrimps Penaeidae target species, a regulation for this area should be drawn up considering 
the main species involved. One option is a regulation based on the Ecosystem Approach to Fisheries (EAF), associated with a permanent monitoring of changes on populational parameters, as sexual proportion, biometric relationships and size. Previous studies in the region have shown that most of the catch (bycatch and target) of the shrimp fishery in Pernambuco occurs in the same area and share the same reproduction season, i.e. between October and March (Lopes et al., 2014, 2017; SiLva et al., 2015a,b, 2016). Hence, the establishment of Marine Protect Areas (MPA) or a fishery-closing period should improve the conservation of the species and marine habitats exploited by this fishery in Pernambuco.

Acknowledgements. We are grateful to the Conselho Nacional de Desenvolvimento Científico e Tecnologico (CNPq) for providing a research grant to F. Lucena Frédou and T. Frédou. This work was carried out under the National Institute on Science and Technology in Tropical Marine Environments - INCT-AmbTropic (CNPq process \#565054/2010-4) and was also partially funded by FACEPE (Fundação de Ciência e Tecnologia do Estado de Pernambuco). We are also grateful for fishermen and members of BIOIMPACT Laboratory for field assistance.

\section{REFERENCES}

Bianchi, G.; Gislason, H.; Graham, K.; Hill, L.; Jin, X.; Koranteng, K.; Manickchand-Heileman, S.; PayÁ, I.; Sainsbury, K.; SancheZ, F. \& ZWANENBURG, K. 2000. Impact of fishing on size composition and diversity of demersal fish communities. ICES Journal of Marine Science 57(3):558-571.

Brewer, D.; Heales, D.; Mildon, D.; Dell, Q.; Fry, G.; Veneables, B. \& Jones, P. 2006. The impact of turtle excluder devices and bycatch reduction devices on diverse tropical marine communities in Australia's northern prawn trawl fishery. Fisheries Research 81(2):176-178.

BroadHurst, M. K.; SuUronen, P. \& Hulme A. 2006. Estimating collateral mortality from towed fishing gear. Fish and Fisheries 7:180-218.

Cervigón, F. R.; Cipriani, W.; Fischer, L.; Garibaldi, M.; Hendrickx, A. J.; Lemus, R.; Márquez, J. M.; Poutiers, G. \& Rodriguez, B. 1992. Guía de campo de las especies comerciales marinas y de aguas salobres de la costa septentrional de sur américa. Rome, FAO. 513p.

Chapman, F. A.; van Eenennaam, J. P. \& Doroshov, S. I. 1996. The reproductive condition of white sturgeon, Acipenser transmontanus, in San Francisco Bay, California. Fishery Bulletin 94(4):628-634.

Chaves, P. T. C. 1998. Estrutura populacional de Pomadasys corvinaeformis (Steindachner) (Teleostei, Haemulidae) na Baía de Guaratuba, Paraná, Brasil. Revista Brasileira de Zoologia 15:203-209.

Chaves, P. T. C. \& CorrêA, C. E. 2000. Temporary use of a coastal ecosystem by the fish, Pomadasys corvinaeformis (Perciformes: Haemulidae), at Guaratuba Bay, Brazil. Revista Brasileira de Oceanografia 48:1-7.

Chellappa, S.; Lima, J. T. A. X.; AraúJo, A. \& Chellappa, N. T. 2010. Ovarian development and spawning of Serra Spanish mackerel in coastal waters of Northeastern Brazil. Brazilian Journal of Biology 70:631-637.

Costa, P. S. \& SAntos, M. E. 1995. Biology and biometrics of Pomadasys corvinaeformis (Steindachner) (Teleostei: Pomadasyidae), in Fortaleza, Ceará, Brazil. Marine Sciences Files 29:20-27.

Courtenay, W. R. \& Sahlman, H. F. 1978. FAO species identification sheets for fishery purposes -Western Central Atlantic (Fishing area 31). FAO, Rome. 326p.

Cox, T.; Lewison, R.; Zydelis, R.; Crowder, L.; Safina, C. \& Read, A. 2007. Comparing effectiveness of experimental and implemented bycatch reduction measures: the ideal and the real. Conservation Biology 21:1155-1164.

Dagnelie, P. 1975. Théorie et méthodes statistiques: applications agronomiques Volume 2: les méthodes de l'inférence statistique. Gembloux, Les presses agronomiques de Gembloux. 464p.

Denadai, M. R.; Santos, F. B.; Bessa, E. \& Fernandez, W. S. 2013. Population biology and diet of Pomadasys corvinaeformis (Perciformes:
Pomadasyidae) in Caraguatatuba Bay, Southeastern Brazil. Revista de Biologia Tropical 61(4):1947-1954.

Fonteles-Filho, A. A. 2011. Oceanografia, biologia e dinâmica populacional de recursos pesqueiros. Fortaleza, UFC Editora. 460p.

FréDou, T.; Ferreira, B. P. \& Letourneur, Y. 2009. Assessing the stocks of the primary snappers caught in Northeastern Brazilian reef systems: 2-A multi-fleet age-structured approach. Fisheries Research 99(2):97-105.

FroESE, R. 2006. Cube law, condition factor and weight-length relationships: history, meta-analysis and recommendations. Journal Applied Ichthyology 22:241-253.

Garcia, J. R.; Mendes, L. F.; Sampaio, C. L. S. \& Lins, J. E. 2010. Biodiversidade Marinha da Bacia Potiguar: Ictiofauna. Rio de Janeiro, Museu Nacional. 195p.

Garcia-Caudillo, J. M.; Cisneros-Mata, M. A. \& Balmori-Ramirez, A. 2000. Performance of a bycatch reduction device in the shrimp fishery of the Gulf of California, Mexico. Biological Conservation 92:199-205.

Gilman, E.; Passfield, K. \& NaKamura, K. 2013. Performance of regional fisheries management organizations: ecosystem-based governance of bycatch and discards. Fish and Fisheries 15:327-351.

Hood, P. \& Johnson, A. K. 2000. Age, growth, mortality, and reproduction of red porgy, Pagrus pagrus, from the eastern Gulf of Mexico. Fishery Bulletin 98:723-735.

JASMINE, S. \& MoLINA, M. A. 2016. Reproductive biology of Mystus vittatus (Bloch, 1794) in the Padma River, Bangladesh. International Journal of Fisheries and Aquatic Studies 4(5):666-669.

KelLeHer, K. 2005. Discards in the World's marine fisheries. An update. FAO Fisheries Technical Paper 470:1-131.

KING, M. 2007. Fisheries biology, assessment and management. Oxford, Blackwell Publishing. 400p.

Le Cren, E. D. 1951. The length, weight relationship and seasonal cycle in gonad weight and condition in perch (Perca fluviatilis). Journal of Animal Ecology 20:201-219.

Lopes, D. F. C; Frédou, F. L; Bezerra, E.; Calazans, N. \& Peixoto, S. 2017. Reproductive cycle of seabob shrimp Xiphopenaeus kroyeri (Crustacea, Penaeidea) from the northeast coast of Brazil. Invertebrate Reproduction \& Development 1:1-5.

Lopes, D. F. C.; Peixoto, S. R. M.; Frédou, F. L. \& Silva, E. F. B. 2014. Population biology of Seabob-shrimp Xiphopenaeus kroyeri (Heller, 1862) captured on the south coast of Pernambuco state, northeastern Brazil. Brazilian Journal of Oceanography 62(4):331-340.

Mian, S.; Hossain, M. A. \& Shah, A. W. 2017. Sex ratio, fecundity and gonado somatic index of spotted snakehead, Channa punctatus (Channidae) from a lentic ecosystem. International Journal of Fisheries and Aquatic Studies 5(1):360-363.

Morey, G.; Moranta, J.; Massutí, E.; Grau, A.; Linde, M.; Riera, F. \& Morales-Nin, B. 2003. Weight-length relationships of littoral to lower slope fishes from the western Mediterranean. Fisheries Research 62(1):89-96.

Munro, J. L.; Gaut, R. \& ReEson, P. H. 1973. The spawning seasons of Caribbean reef fishes. Journal of Fish Biology 5:69-84.

Parsons, T. R.; Souza, L. M. \& Chaves, P. T. 2007. Atividade reprodutiva de peixes (Teleostei) e o defeso da pesca de arrasto no litoral norte de Santa Catarina, Brasil. Revista Brasileira de Zoologia 24(4):1113-1121.

PASCOE, S. 1997. Bycatch management and the economics of discarding. FAO Fisheries Technical Paper 370:1-137.

Potts, J. C. \& Manooch, C. S. 2001. Differences in the age and growth of the white grunt (Haemulon plumieri) from North Carolina and South Carolina compared with southeast Florida. Bulletin of Marine Science 68(1):1-12.

RijnsdorP, A. D.; Damme, C. J. G. V. \& Witthames, P. R. 2010. Implications of fisheries induced changes in stock structure and reproductive potential for stock recovery of a sex dimorphic species, North Sea plaice. ICES Journal of Marine Science 67:1931-1938

Silva, A. M.; Oliveira, M. R. \& Chellapa, S. 2012. Biologia reprodutiva do coró, Pomadasys corvinaeformis Steindachner (Osteichthyes: Haemulidae) das águas costeiras do Rio Grande do Norte, Brasil. Biota Amazônia 2(2):15-24.

Silva, C.; Viana, A. P.; FrÉdou, F. L. \& FrÉDou, T. 2015a. Aspects of the reproductive biology of Sciaenidae captured as bycatch in the prawn 
trawling in the northeastern Brazil. Acta Scientiarum, Biological Sciences 37:1-8.

Silva, E. F. B.; Calazans, N.; Nolé, L.; Branco, T. C.; Soares, R.; Guerra, M.; FrÉDou, F. L. \& Peixoto, S. 2016. Reproductive dynamics of the southern pink shrimp Farfantepenaeus subtilis in northeastern Brazil. Aquatic Biology 25:29-35.

Silva, E. F. B.; Calazans, N.; Nolé, L.; Viana, A. P.; Soares, R.; Peixoto, S. \& FrÉDOU, F. L. 2015b. Population dynamics of the pink shrimp Farfantepenaeus subtilis (Pérez-Farfante, 1967) in northeastern Brazil. Journal of Crustacean Biology 35:132-139.

Sмiтн, C. L. 1997. National Audubon Society Field Guide to Tropical Marine Fishes: Caribbean, Gulf of Mexico, Florida, Bahamas, Bermuda. New York, Chanticleer Press. 720p.

SOKaL, R. R. \& RoHLF, F. J.1987. Introduction to biostatistics. New York, Freeman Publication. 363p.

Souza, L. M. \& Chaves, P. T. 2007. Atividade reprodutiva de peixes
(Teleostei) e o defeso da pesca de arrasto no litoral norte de Santa Catarina, Brasil. Revista Brasileira de Zoologia 24(4):1113-1121.

Stratoudakis, Y.; Bernal, M.; Ganias, K. \& Uriarte, A. 2006. The daily egg production method: recent advances, current applications and future challenges. Fish and Fisheries 7:35-57.

Tischer, M. \& SANTos, M. C. F. 2002. Pesca e variação sazonal da ictiofauna acompanhante e dos camarões peneídeos capturados pela frota motorizada no litoral sul de Pernambuco. Boletim técnico CEPENE 10(1):221-238

VAZZOLER, A. E. A. M. 1996. Biologia da reprodução de peixes teleósteos: teoria e prática. Maringá, EDUEM. 169p.

Vianna, M.; Costa, F. E. S. \& Ferreira, C. N. 2004. Length-weight relationship of fish caught as by-catch by shrimp fishery in the southeastern coast of Brazil. Boletim do Instituto de Pesca 30(1):81-85.

ZAR, J. H. 2009. Biostatistical Analysis. Prentice-Hall International. Upper Saddle River, Prentice Hall. 960p. 